\title{
THE EFFECT OF USING TONGUE TWISTER TO IMPROVE STUDENTS' PRONUNCIATION MASTERY
}

\author{
Rizki Dwi Cahyani ${ }^{1}$, Efrini Panjaitan ${ }^{2}$ \\ Mahasiswa Pendidikan Bahasa Inggris STKIP Budidaya Binjai ${ }^{1}$, Dosen STKIP Budidaya \\ Binjai $^{2}$ \\ e-mail : Rizki.dwc21@gmail.com ${ }^{1}$, efrinipanjaitan@gmail.com²
}

\begin{abstract}
This study aimed to find out whether using Tongue Twister to Improve Students' Pronunciation Mastery at the Tenth Grade Students of SMA Swasta Melati Binjai In Academic Year 2019/2020. In this study, used Tongue Twister as the independent variable $(\mathrm{X})$ and students' pronunciation mastery as the dependent variable (Y), with the hypothesis: using Tongue Twister significantly affects students' pronunciation mastery of the 2019/2020 tenth grade students of SMA Swasta Melati Binjai Senior High School. The population of this study was the 2019/2020 tenth grade students of SMA Swasta Melati Binjai Senior High School. Which consisted of 62 students. The sample was taken by using cluster random sampling, that consist of 62 students. Then, the sample was divided into two groups, the group taught by using Tongue Twister was as the experimental group and the group taught without Tongue Twister was as the control group. The writer used speaking test as the instrument of collecting data. The data was analyzed by using t-test formula. Based on the data analysis, it was found that the value of t-observed ( $t 0)$ was higher than the value of $\mathrm{t}$-table, $(\mathrm{t}$-observed $=18.08>\mathrm{t}$-table $=1.671$ ). Therefore, the hypothesis proposed by the writer was accepted. In the other words, using Tongue Twister significantly affects the students' pronunciation mastery of the 2019/2020 tenth grade students at SMA Swasta Melati Binjai Senior High School.
\end{abstract}

Key Words: Tongue Twister, Pronunciation Mastery 


\section{INTRODUCTION}

Language is the tool of communication which very important role to express an intention to other people. Language also is used by people to express and receive some information, message, idea, emotions (Collin, 2019). There are many kinds of languages used by people such English, Spanish, Arabic Indonesian, etc. It depends on where the people live. One of those kinds of languages is English. In many countries English has a particular role as the language of communication between people who are speakers of the different indigenous languages (Kenworthy, 2010:3).

Nowadays, English is very important not only in communication activities but also in science and modern technology. English is very popular language all over the world including Indonesia. English is the first foreign language taught at every school in Indonesia. The Indonesian government chooses English as the first foreign language to be taught in school from elementary school to university students, hence that they realize how important English in their life that they can use to communicate with other people in the world. English consists of four basic skills that student must master, they are listening, speaking, reading, and writing.

Based on the concept and function, English has the purpose to develop those four skills and also the language components namely vocabulary, structure and pronunciation (in speech) or spelling (in writing) which supports students mastering well. But in speaking English we often find the difficulty in pronouncing the English word. Pronunciation is an important form of communication especially for those who study at the junior high school.

However, most student have the difficulty in pronouncing English language, as one of the important pronunciations in English skill. The discussion about pronunciation also consider important, especially for student in EFL environment. Furthermore, the advantage of knowing the pronunciation place is important, (Harmer, 2010, 183) said that "Pronunciation teaching not only makes students aware of different sounds and sound features (and what these mean), but can also improve their speaking immeasurably". Most student in Indonesia consider English as a difficult subject which makes them frustrated. Especially in senior high school, based on observation in SMA Swasta Melati Binjai; the first majority of students are Javanese and their mother language are Javanese. The students most often use Javanese as mother language to communication with other in the class. The second, the difficulty in composing the word or sentences, understanding grammar and how to use them, and how to pronounce the word correctly. The last, the students are unconfident, feel shy in practicing speaking, and being afraid in making mistakes in speaking English. And also, the writer found some problem that students faced in speaking are accuracy in pronunciation of student are still low. This difficulty is caused by psychology factor of the students and lack of teachers' creativity in teaching speaking especially in pronunciation English subject at the tenth-grade students of SMA Swasta Melati Binjai in Academic Year 2019/2020. From this reality, the teachers must be creative to increase the students' achievement to make success in learning. In order to enable students to express their idea in pronunciation, teacher must be creating varieties method in teaching. Many technique and methods had been conducted by the teacher; one of the alternatives in teaching pronunciation is using tongue twister. Using tongue twister's strategy in learning pronunciation is very important to 
increase the student's pronunciation ability. So, that student will be the learners can use the role of pronunciation accuracy in English language so for the future students can speak English accuracy and fluency. Considering the previous description, the writer conducted a research under the title The Effect of Tongue Twister to Improve Student's Pronunciation Mastery at The Tenth Grade of SMA Swasta Melati Binjai in Academic Year 2019/2020.

\section{RESEARCH METHODOLOGY}

The study was carried out at SMA Swasta Melati Binjai. It is located at Jl. Haryono MT No. 314 Kel. Jati Karya, Binjai Utara, Binjai. Especially on the Tenth-grade students in academic year 2019/2020. This study was conducted from November 2019. It is the period in the first semester of new academic year. The type of this research is experimental research, precisely Quasi experimental research. This research design involved an experimental group and a control group, both are given a pretest and a posttest. Experimental group received the treatment, however the control group do not. The population of the research is the tenthgrade students of SMA Swasta Melati Binjai in academic year 2019/2020. It consists of two classes, numbering to 62 students altogether. Then, the writer decides to take 62 out of the population as the sample of this research and group them as experimental class and control class. The dependent variable in this study is the students' pronunciation mastery, while the independent one is Tongue Twister Method.

\section{DATA AND DATA ANALYSIS}

The purpose of this research is to give the report the data description and to analyze score of pre-test and post-test of experiment and control class. The researcher compares the achievement of pre-test and post-test, to know whether tongue twister technique is effective in teaching student's pronunciation mastery.

The researcher held this research at the tenth grade of SMA Swasta Melati Binjai in academic year 2019/2020. The researcher took 62 students for sample, 31 students from class $\mathrm{X}-1$ as an experimental group, and 31 students from class $\mathrm{X}-2$ as a control group.

In this research, the researcher gave test to the students for twice, first test is called pre- test, and the second test called post-test.

\section{The Data of Control Class}

Students in the control class are given learning about pronunciation mastery by applying the conventional method, that is the lecture method commonly applied by the teacher. Furthermore, at the first lesson students are given tongue twister test as a pretest, and at the end of the lesson students are given tongue twister test as a post-test.

Before doing the calculation by using $\mathrm{t}$ test, the data of students' pre-test and posttest score of controlled class and experiment class that had been collected is described in the tables as follows:

\begin{tabular}{lccc}
$\begin{array}{l}\text { Table } \\
\text { No. }\end{array}$ & Students & Score of Controlled Class \\
Pample & Pre-test & Post-test \\
\hline 1. & Y-001 & 36 & 46 \\
\hline 2. & Y-002 & 36 & 46 \\
\hline 3. & Y-003 & 42 & 52 \\
\hline 4. & Y-004 & 36 & 46 \\
\hline 5. & Y-005 & 36 & 42 \\
\hline 6. & Y-006 & 40 & 42 \\
\hline 7. & Y-007 & 42 & 52 \\
\hline 8. & $Y-008$ & 42 & 56 \\
\hline 9. & $Y-009$ & 45 & 62 \\
\hline 10. & $Y-010$ & 42 & 60 \\
\hline 11. & $Y-011$ & 40 & 42 \\
\hline 12. & $Y-012$ & 46 & 52 \\
\hline
\end{tabular}




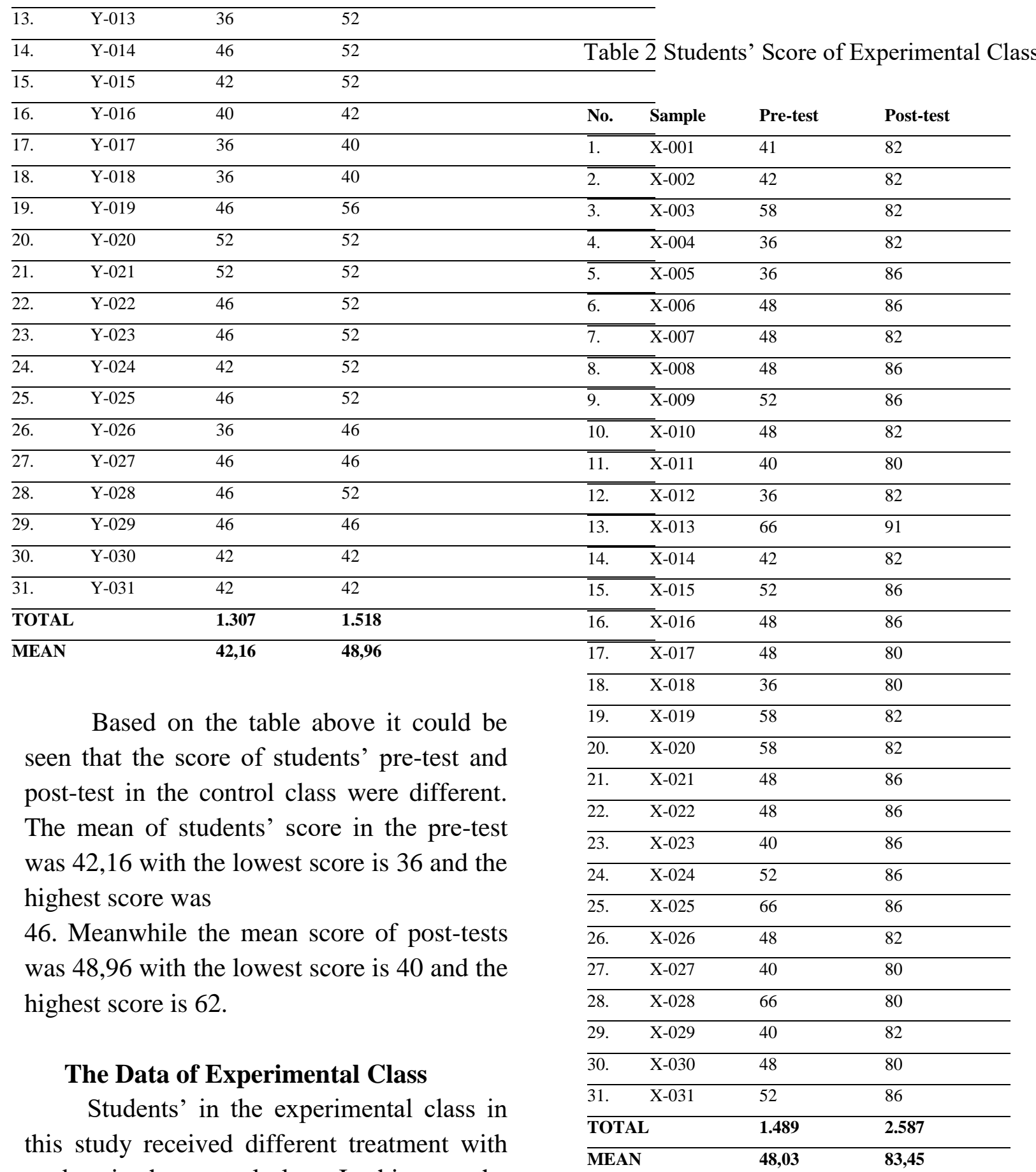
student in the control class. In this case the students' in the experimental class was given the learning by applying tongue twister strategy. Furthermore, at the end of the lesson, students were given the same test as the control class. 
Based on the table above, the mean of students' score in the pre-test was 48,03 , with the lowest score was 36 and the highest score was 66. Meanwhile the mean score of posttests was 83,45 with the lowest score was 80 and the highest score was 91 .

\section{Hypothesis of test}

Before doing the calculation by doing $\mathrm{t}$ test, the data of students' pre-test and posttest scores of controlled class and experimental class that had been collected is described in (see appendix):

Based on the data in the table above, it showed that the students' achievement in vocabulary mastery by using Tongue Twister in experimental class was higher than the students' in the controlled class without tongue twister.

The data of students' score was analyzed by using t-test to prove whether there was any significant different between students' ability in tongue twister mastery in the experimental class as the $\mathrm{X}$ variable and controlled class as the $\mathrm{Y}$ variable. But, before using the formula of t-test, the students' score in the experimental and controlled class were tabulated to calculate the gained score of each class. It could be seen as follows:

Table 3 Gained Score of Controlled Class

\begin{tabular}{|c|c|c|c|c|}
\hline No. & Sample & & $\begin{array}{l}\text { Post- } \\
\text { test }\end{array}$ & $\begin{array}{l}\text { Gained } \\
\text { Score }\end{array}$ \\
\hline 1. & Y-001 & 36 & 46 & 10 \\
\hline 2. & Y-002 & 36 & 46 & 10 \\
\hline 3. & Y-003 & 42 & 52 & 10 \\
\hline 4. & Y-004 & 36 & 46 & 10 \\
\hline 5. & Y-005 & 36 & 42 & 6 \\
\hline 6. & Y-006 & 40 & 42 & 2 \\
\hline 7. & Y-007 & 42 & 52 & 10 \\
\hline 8. & Y-008 & 42 & 56 & 14 \\
\hline 9. & Y-009 & 45 & 62 & 7 \\
\hline 10. & Y-010 & 42 & 60 & 18 \\
\hline 11. & Y-011 & 40 & 42 & 2 \\
\hline
\end{tabular}

\begin{tabular}{|c|c|c|c|c|}
\hline 12. & Y-012 & 46 & 52 & 6 \\
\hline 13. & Y-013 & 36 & 52 & 16 \\
\hline 14. & Y-014 & 46 & 52 & 6 \\
\hline 15. & Y-015 & 42 & 52 & 10 \\
\hline 16. & Y-016 & 40 & 42 & 2 \\
\hline 17. & Y-017 & 36 & 40 & 4 \\
\hline 18. & Y-018 & 36 & 40 & 4 \\
\hline 19. & Y-019 & 46 & 56 & 10 \\
\hline 20. & Y-020 & 52 & 52 & 0 \\
\hline 21. & Y-021 & 52 & 52 & 0 \\
\hline 22. & Y-022 & 46 & 52 & 6 \\
\hline 23. & Y-023 & 46 & 52 & 6 \\
\hline 24. & Y-024 & 42 & 52 & 10 \\
\hline 25. & Y-025 & 46 & 52 & 6 \\
\hline 26. & Y-026 & 36 & 46 & 10 \\
\hline 27. & Y-027 & 46 & 46 & 0 \\
\hline 28. & Y-028 & 46 & 52 & 6 \\
\hline 29. & Y-029 & 46 & 46 & 0 \\
\hline 30. & Y-030 & 42 & 42 & 0 \\
\hline 31. & Y-031 & 42 & 42 & 0 \\
\hline \multicolumn{2}{|c|}{ TOTAL } & 1.307 & 1.518 & 201 \\
\hline \multicolumn{2}{|c|}{ MEAN } & 42,16 & 48,96 & 6,48 \\
\hline
\end{tabular}

Table 4. Gained Score of Experimental Class No. Sample Pre-test Post-test Gained Score

\begin{tabular}{lllll}
\hline 1. & $\mathrm{X}-001$ & 41 & 82 & 41 \\
\hline 2. & $\mathrm{X}-002$ & 42 & 82 & 40 \\
\hline 3. & $\mathrm{X}-003$ & 58 & 82 & 24 \\
\hline 4. & $\mathrm{X}-004$ & 36 & 82 & 46 \\
\hline 5. & $\mathrm{X}-005$ & 36 & 86 & 50 \\
\hline 6. & $\mathrm{X}-006$ & 48 & 86 & 38 \\
\hline 7. & $\mathrm{X}-007$ & 48 & 82 & 34 \\
\hline 8. & $\mathrm{X}-008$ & 48 & 86 & 38 \\
\hline 9. & $\mathrm{X}-009$ & 52 & 86 & 34 \\
\hline 10. & $\mathrm{X}-010$ & 48 & 82 & 34 \\
\hline 11. & $\mathrm{X}-011$ & 40 & 80 & 40 \\
\hline 12. & $\mathrm{X}-012$ & 36 & 82 & 46 \\
\hline 13. & $\mathrm{X}-013$ & 66 & 91 & 25 \\
\hline 14. & $\mathrm{X}-014$ & 42 & 82 & 40 \\
\hline 15. & $\mathrm{X}-015$ & 52 & 86 & 34 \\
\hline 16. & $\mathrm{X}-016$ & 48 & 86 & 38 \\
\hline 17. & $\mathrm{X}-017$ & 48 & 80 & 32 \\
\hline 18. & $\mathrm{X}-018$ & 36 & 80 & 44 \\
\hline 19. & $\mathrm{X}-019$ & 58 & 82 & 38 \\
\hline 20. & $\mathrm{X}-020$ & 58 & 82 & 38 \\
\hline 21. & $\mathrm{X}-021$ & 48 & 86 & 86 \\
\hline 22. & $\mathrm{X}-022$ & 48 & & 38 \\
\hline & & & 56 & \\
\hline
\end{tabular}




\begin{tabular}{lllll}
\hline 23. & X-023 & 40 & 86 & 46 \\
\hline 24. & X-024 & 52 & 86 & 34 \\
\hline 25. & X-025 & 66 & 86 & 20 \\
\hline 26. & X-026 & 48 & 82 & 34 \\
\hline 27. & X-027 & 40 & 80 & 40 \\
\hline 28. & X-028 & 66 & 80 & 14 \\
\hline 29. & X-029 & 40 & 82 & 42 \\
\hline 30. & X-030 & 48 & 80 & 32 \\
\hline 31. & X-031 & $\mathbf{5 2}$ & 86 & 34 \\
\hline TOTAL & $\mathbf{1 . 4 8 9}$ & $\mathbf{2 . 5 8 7}$ & $\mathbf{1 . 0 9 8}$ \\
\hline MEAN & $\mathbf{4 8 , 0 3}$ & $\mathbf{8 3 , 4 5}$ & $\mathbf{3 5 . 4 1}$
\end{tabular}

According the data in the table above, the result of students' pretest and posttest further in each class was calculated by using ttest in some steps as follows:

1. Determining mean of variable $\mathrm{X}$, with formula as follows:

$$
\begin{array}{ll}
\mathrm{Mx} & =\frac{\Sigma \mathrm{x}}{\mathrm{N} 1} \\
\mathrm{Mx} & =35,41
\end{array}
$$

2. Determining mean of variable $Y$, with formula as follows:

$\mathrm{My}=\frac{\sum \mathrm{y}}{\mathrm{N} 1} \quad \mathrm{My}=\frac{201}{31} \quad \mathrm{My}=6,48$

3. Determining standard of deviation score of variable $\mathrm{X}$, with formula as follows:

$$
\begin{aligned}
& S D x=\sqrt{\frac{\mathrm{X} 2}{\mathrm{~N} 1}} \quad S D x=\sqrt{\frac{2030}{31}} \\
& S D x=\sqrt{60} \\
& S D x=7,8
\end{aligned}
$$

4. Determining the standard of deviation score of variable $\mathrm{Y}$, with formula as follows

$$
\begin{gathered}
S D y=\sqrt{\frac{\mathrm{y} 2}{\mathrm{~N} 1}} \quad S D y=\sqrt{\frac{718}{31}} \\
S D y=\sqrt{23}
\end{gathered}
$$

5. Determining standard error of mean of variable $\mathrm{X}$, with formula as follows:

$$
\begin{aligned}
& \text { SEMx }=\frac{S D x}{\sqrt{N}-1} \quad \text { SEMx }=\frac{7,8}{\sqrt{31}-1} \\
& \text { SEMx }=\frac{7,8}{\sqrt{30}} \quad \text { SEMx }=\frac{7,8}{\sqrt{5,47}} \\
& \text { SEMX }=1,42
\end{aligned}
$$

6. Determining standard error of mean of variable $\mathrm{Y}$, with formula as follows:

$$
\begin{aligned}
& \text { SEMy }=\frac{S D y}{\sqrt{N}-1} \quad \text { SEMy }=\frac{4,7}{\sqrt{31}-1} \\
& \text { SEMy }=\frac{4,7}{\sqrt{30}} \quad \text { SEMy }=\frac{4,7}{\sqrt{5,47}} \\
& \text { SEMY }=0,85
\end{aligned}
$$

7. Determining standard error of different mean of variable $\mathrm{X}$ and variable $\mathrm{Y}$, with formula as follows:

$$
\begin{array}{r}
S E M x-M y=\sqrt{S E M x 2+S E M Y 2} \\
S E M x-M y=\sqrt{(1,42) 2+(0,85) 2} \\
S E M x-M y=\sqrt{2+0,72} \\
S E M x-M y=\sqrt{2,72} \text { SEMx- }
\end{array}
$$$$
M y=1,6
$$

8. Determining $\mathrm{t}_{\mathrm{o}}$, with formula as follows:

$$
\begin{gathered}
\text { to }=\frac{M x-M y}{S E M x-M y} \quad \text { to }=\frac{35,41-6,48}{1,6} \\
\text { to }=\frac{28,93}{1,6} \quad \text { to }=18,08
\end{gathered}
$$

\section{Discussion}

There was a significant difference on the student's pronunciation mastery between the students were taught by using tongue twister and that students were taught by conventional method. The students' pronunciation mastery was taught by using tongue twister is higher than those students were taught by using conventional method.

The application of tongue twister allows an instruction to pronounced tongue twister sentence. Therefore, the students can pronounce clearly when they speak English.

It means that tongue twister technique has shown the significance influence for students' pronunciation and this strategy can be used as a good strategy to improve student's pronunciation skill.

\section{CONCLUSION AND SUGGESTION}

\section{Conclusion}

Based on the research entitled about The Effectiveness of Tongue Twisters Technique toward Student Pronunciation Skills, and concerning to the result and discussion, the researcher concludes that: 
1. The students' pronunciation ability at the tenth grade of SMA Swasta Melati Binjai was good. The result can be seen in the description of chapter IV that the highest score is 86 for experiment class and it is bigger than control class while the biggest score for control class is 62 .

2. Pronunciation is one of skill that must be mastered in English language. In the pronunciation, the researcher could recognize generally about student's problem in pronunciation, they are initial consonant, final consonant, simple vowel, and diphthongs. Those four aspects are considered hard to be pronounced by the students.

3. Based on the result that is described on previous chapter proved that tongue twisters is effective in increase students' pronunciation skill. The evidence is when students practice their pronunciation by using tongue twister's technique. It shows that tongue twisters' technique can help the students to increase their pronunciation skill. Through tongue twister's technique students can enjoy the teaching and learning process.

To test the hypothesis based on data that has been obtained, then in accordance with the provisions that have been established that the hypothesis accepted if $\mathrm{t}$-count $>\mathrm{t}$-table. Has been known the $t_{\text {table }}$ is 1.671 , then $18.08>1.671$. It concluded the hypothesis is accepted, so it can be concluded that treatment with Tongue Twisters Technique Effect on Students' pronunciation ability of the Tenth Grade Students of SMA Swasta Melati Binjai of the tenth grade Students in Academic Year 2019/2020.

\section{Suggestion}

Hence, in the final of this paper, the researcher would like to give some suggestions:

1. The students should recognize the difficulties in English pronunciation in order to correct all of their mistakes when they produce/pronounce the word.

2. Teacher of English should be master the technique of introducing intonation, in order to get more interesting atmosphere of learning and teaching process.

3. Choosing a technique or strategy in teaching pronunciation is very important because some students consider that English pronunciation is very difficult. Therefore, the teacher must have appropriate strategy, make situation enjoyable to teaching English and give more understanding to the students about the important of the pronunciation.

\section{REFERENCES}

Harmer Jeremy. 2010. The Practice of Teaching Language $6^{\text {th }} \mathrm{Ed}$, (New York: Longman

Jack R. Fraenkel, Wallen, Norman E., dan Hyun, Helen H. 2011. How to Design and Evaluate in Education. New York: McGrawHill

Kenworthy Joanne. 2010. Teaching English Pronunciation. New York: Longman Group

M. Cintron Karim, Tongue Twister. (http://www.eslpartyland.com/articles/ tongue- twisters.html september 19th, 2019)

Matthew. 2010." Goldrick and sheila E Blumstein, Cascading Activation from Phonological Planning to Articulatory Processes: Evidence from Tongue Twisters, Department of Cognitive and Linguistic". Science Brown University \& Department of 
Linguistics, Northwestern

University

Collins Dictionary “ Definition of Language"

(https://www.collinsdictionary.co $\mathrm{m} /$ dictionary/english/language, access on 14 Oktober 2019 
